\title{
Special issue "The next Marmara earthquake: disaster mitigation, recovery, and early warning"
}

Takane Hori ${ }^{*}$, Ali Pinar ${ }^{2}$, Ocal Necmioglu ${ }^{2}$, Muneo Hori ${ }^{3}$ and Azusa Nishizawa ${ }^{4}$

The Marmara Sea, accommodating the fault segments of a major transform fault, is well known as a seismic gap along the North Anatolian Fault (NAF), running through the northern part of Turkey and connecting the East Anatolian convergent area with the Hellenic subduction zone (e.g., Pınar 1943; Toksöz et al. 1979; Pondard et al. 2007; Şengör et al. 2014). It is obvious from historical records spanning more than 2000 years that the region is subject to frequent strong shaking that is likely associated with tsunami waves, threatening heavily populated and industrialized locations (Ambraseys 2002; Erdik et al. 2004; Hébert et al. 2005). In the twentieth century, magnitude (M) 7-class earthquakes sequentially occurred from east to west along the NAF zone, as shown in Fig. 1 (Stein et al. 1997). The last two successive events hit the eastern Marmara region in August 17 and November 12, 1999 , known as Izmit $(\mathrm{Mw}=7.5)$ and Düzce $(\mathrm{Mw}=7.2)$ earthquakes, respectively, killing about 20,000 people and devastating the region. On the other hand, at the western edge of Marmara Sea, an $M \sim 7$ earthquake occurred in 1912, rupturing onshore and offshore fault segments where 4-5 $\mathrm{m}$ lateral displacements were measured (Armijo et al. 2005; Aksoy et al. 2010). Furthermore, in the Marmara Sea, it has been considered that the last M7 class earthquake occurred in 1766. With an average slip rate of $2 \mathrm{~cm}$ /year, several meters have accumulated over the past 250 years (Straub 1996; Meade et al. 2002). Based on a time-dependent model that includes the coseismic and post-seismic effects of the 1999 Kocaeli earthquake with moment magnitude $\mathrm{Mw}=7.4$, Parsons (2004) concluded that the probability of an earthquake with $\mathrm{Mw}>7$ in the Sea of Marmara near Istanbul is $35-70 \%$ in the next 30 years. According to a 2011 study, an earthquake

\footnotetext{
*Correspondence: horit@jamstec.go.jp

1 Japan Agency for Marine-Earth Science and Technology, Yokohama, Japan

Full list of author information is available at the end of the article
}

with $\mathrm{Mw}=7.25$ on the Main Marmara Fault is expected to heavily damage or destroy $2-4 \%$ of the near $1,000,000$ buildings in Istanbul, which has a population of around 13 million, with $9-15 \%$ of the buildings receiving medium damage and $20-34 \%$ of the buildings lightly damaged (Erdik 2013).

The aim of this special issue is to gather information about the risk of another Marmara earthquake from the latest geophysical, geological, geotechnical, computational, and building science research results to discuss ways of mitigating disaster in advance. The collection of 12 papers constituting this special issue is based on recent research on imaging the crustal structure, the geometry of the fault segments and their microseismicity features, source characteristics of large earthquakes inferred from historical seismograms, tsunami hazard assessment and mitigation studies, site response evaluations, and development of an integrated earthquake simulation system.

Polat et al. (2016) portrayed a tomographic image of the crust beneath the Sea of Marmara and its close surrounding area, derived from a dataset of more than ninety thousand P- and S-wave arrival times from local earthquakes recorded at land-based stations and ocean bottom seismographs. Their seismic velocity images illustrate positive anomalies nearby the fault segments of NAF, correlating with regions of higher seismicity. The study of Yamamoto et al. (2015) closely inspects the NAF segments beneath the Sea of Marmara, especially the fault geometry and their seismic activity carried out by the deployment of 15 OBS stations at locations close to the Main Marmara Fault (MMF). A deeper than previously known seismogenic zone, extending to the lower crust, is one of the most striking features derived from the OBS observations. The offshore seismic stations nearby MMF constrained the depth, dip, and lateral extent of the seismicity much better and, consequently, the geometry of the fault 


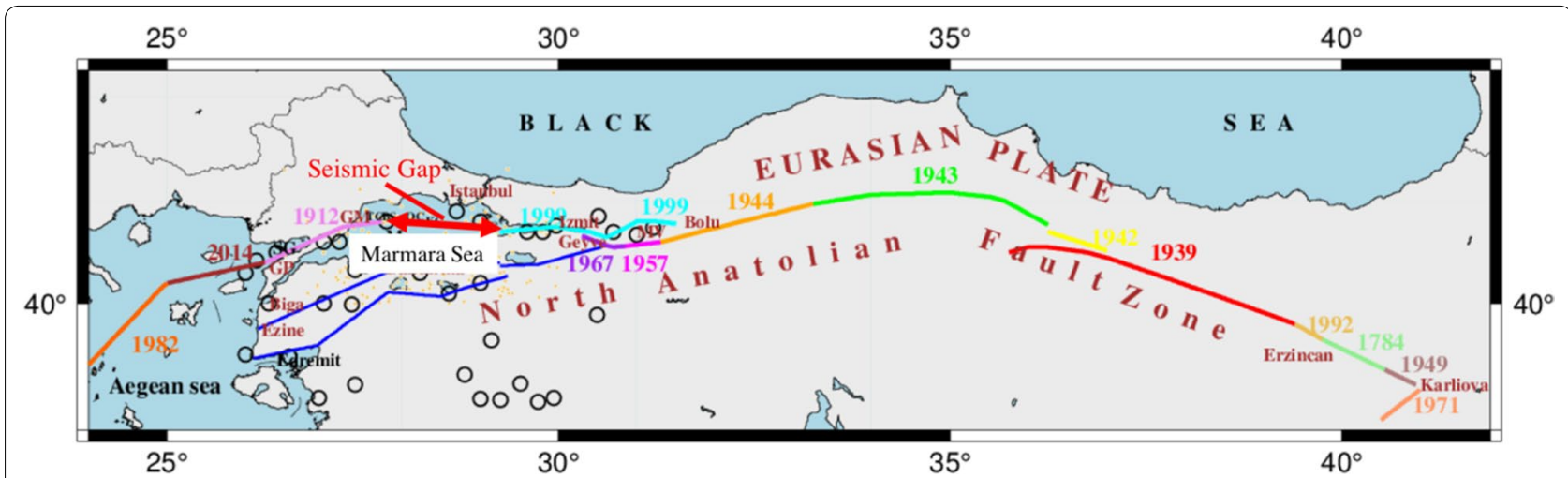

Fig. 1 Surface rupture extent associated with major earthquakes along NAF

segments. The geometry between the fault segments and the orientation of the maximum horizontal compressive stress axis is correlated through the frictional strength of faults in the study presented by Pinar et al. (2016). They use the frequency distribution of $\mathrm{P}$ - and $\mathrm{T}$-axes of the focal mechanisms of events taking place around three fault segments in the eastern Marmara. A low frictional coefficient for the Princes' Islands segment and high frictional coefficients for the Yalova-Çinarcik and YalovaHersek segments are derived by the authors.

Further information on the fault segmentation of NAF in the Marmara Sea and north Aegean Sea regions is determined by modeling the waveforms at broadband land stations to retrieve the source properties of moderate to large events, estimating the CMT parameters and source time functions (Nakano et al. 2016). The source time function of the 2014 North Aegean earthquake $(\mathrm{Mw}=6.9)$ provides evidence on ruptures of different fault segments associated with the mainshock. Moreover, the CMT solutions derived for the events taking place along the MMF fault indicate fault parallel T-axis orientations, suggesting segmentation and development of local extension features. Baştürk et al. (2016) relocated two ancient moderate-sized earthquakes, using historical seismograms of events occurring in 1935 in the proximity of Marmara Island. Applying modern techniques to the old seismograms, CMT parameters for the two events are retrieved that indicate predominantly normal faulting mechanisms taking place at the upper crust. Similar source parameters are obtained for the 1963 Çinarcık earthquake, whose location was long a subject of debate. The location of the fault segment ruptured by the 1963 earthquake and its source mechanism is of great importance in seismic hazard assessment studies. Mert et al. (2016) tried to predict the strong ground motions to be generated by a rupture on the Princes' Islands segment, which lies beneath the Çınarcık basin, using physically based probabilistic seismic hazard analysis (PSHA) methodology where broadband strong ground motion simulations are conducted. To generate the high-frequency $(0.5-20 \mathrm{~Hz})$ part of the broadband earthquake simulation, real, small-magnitude earthquakes recorded by a local seismic array were used as empirical Green's functions. As for frequencies below $0.5 \mathrm{~Hz}$, the synthetic Green's functions are calculated by an explicit 2D/3D elastic finite difference wave propagation routine.

Aytore et al. (2016) used NAMI-DANCE code to carry out high-resolution tsunami simulations in the Marmara Sea, focusing on Haydarpaşa Port in the megacity of Istanbul, and computed the tsunami parameters in and around the port. They observed that the stability of the breakwaters is one of the major factors that influence whether agitation and inundation can be diminished in the event of a tsunami in Haydarpaşa Port, as harbor protection structures have not been designed to withstand tsunamis. The flow depth, momentum fluxes, and current pattern were identified as the other factors that cause unexpected circulation and uncontrolled movements of objects on land and vessels in the sea. Cankaya et al. (2016) applied a new methodology in Yenikapı region as a case study for tsunami vulnerability assessment, based on high-resolution coastal inundation modeling. Using NAMI-DANCE code, they constructed vulnerability at location and evacuation resilience maps, using the analytical hierarchical process (AHP) method of multicriteria decision analysis (MCDA) to define the tsunami human vulnerability of the region. The vulnerability at location map is composed of metropolitan use, geology, elevation, and distance from shoreline layers, whereas the evacuation resilience map considers slope, distance within flat areas, distance to buildings, and distance to road networks layers. Following this, they computed the tsunami risk map from the proposed new relationship, which uses flow depth maps, vulnerability at location 
maps, and evacuation resilience maps. Necmioglu (2016) indicated that in the absence of adequate post-earthquake assembly areas, especially in heavily urbanized Istanbul, citizens would be rushing to landfill assembly and recreational areas in the coastal parts of the city after a major earthquake. To address this, he proposed a model for a tsunami warning system specific for the Marmara region that is strongly coupled with the earthquake early warning system and stakeholders of tsunami mitigation activities, such as the local and regional components of disaster and emergency management and civil protection units. This would ensure that the citizens would stay away from the coastline in case of a large earthquake. Necmioglu also discussed associated challenges, such as decoupled earthquake and tsunami mitigation activities in the Marmara region.

Istanbul is the largest metropolitan city expected to be hit by the impending Marmara Sea earthquake. Rapid response systems are effective in mitigating the loss of life and property. Zülfikar et al. (2017) describe how realtime ground motion shaking maps are constructed from the strong motion stations distributed throughout the densely populated areas of the city. Building damage estimation is then computed by using grid-based building inventory, and the related loss is estimated. Zülfikar et al. (2017) further inform how rapidly estimated data enable public and private emergency management authorities to take action to allocate and prioritize resources, minimizing casualties in urban areas during immediate postearthquake periods. Site response plays an important role in generating shake maps. Karagoz et al. (2015) explore the $\mathrm{S}$-wave velocity structure of shallow soils using microtremors to estimate site responses in Tekirdag and the surrounding area. They collected data at 44 sites in Tekirdag, Marmara Ereglisi, Corlu, and Muratll, and estimated phase velocities of Rayleigh waves from the microtremor data using a spatial autocorrelation method. A hybrid genetic simulated annealing algorithm was applied by the authors to obtain a 1D S-wave velocity structure at each site. All the studies constituting this special issue contribute to some extent to an integrated earthquake simulation (IES) system that was developed for Istanbul by Sahin et al. (2016). The IES for Istanbul is built in MATLAB and includes site response analysis as well as structural seismic response analysis of existing buildings; building models are made by using GIS databases. An initial application is performed in the Zeytinburnu District of Istanbul, and the results are expressed in the form of spatial distribution of ground motion and building responses. The IES analysis illustrates a nonuniform distribution of seismic responses, indicating the possibility that there are more severely damaged areas in the district compared with others.
The Marmara region, long ago identified as a seismic gap, is waiting for the impending major earthquake to rupture the MMF segments. Meanwhile, several studies have been carried out to determine the seismic hazard level, the fault geometry and segmentation, mitigation of seismic risk, rapid response, and early warning. All these subjects are tackled in this special issue, making a valuable contribution on the existing information that is constrained by high-quality data acquired in the frame of the MarDIM project, a joint effort of Turkish and Japanese scientists financially supported by JICA, JST and the Ministry of Development in Turkey.

\section{Author details \\ Japan Agency for Marine-Earth Science and Technology, Yokohama, Japan. ${ }^{2}$ Kandilli Observatory and Earthquake Research Institute, Bogazici University, Istanbul, Turkey. ${ }^{3}$ Earthquake Research Institute, The University of Tokyo, \\ Tokyo, Japan. ${ }^{4}$ Hydrographic and Oceanographic Department, Japan Coast Guard, Tokyo, Japan.}

\section{Publisher's Note}

Springer Nature remains neutral with regard to jurisdictional claims in published maps and institutional affiliations.

Received: 12 April 2017 Accepted: 25 April 2017

Published online: 05 May 2017

\footnotetext{
References

Aksoy ME, Meghraoui M, Vallée M, Çakır Z (2010) Rupture characteristics of the A.D. 1912 Mürefte (Ganos) earthquake segment of the North Anatolian fault (western Turkey). Geology 38(11):991-994. doi:10.1130/G31447.1 Ambraseys N (2002) The seismic activity of the Marmara sea region over the last 2000 years. Bull Seismol Soc Am 92:1-18. doi:10.1785/0120000843 Armijo R, Pondard N, Meyer B, Ucarkus G, Lepinay BM, Malavieille J, Dominguez S, Gustcher MA, Schmidt S, Beck C, Cagatay N, Cakir Z, Imren C, Eris K, Natalin B, Ozalaybey S, Tolun L, Lefevre I, Seeber L, Gasperini L, Rangin C, Emre Ö, Sarikavak K (2005) Submarine fault scarps in the Sea of Marmara pull-apart (North Anatolian Fault): implications for seismic hazard in Istanbul. Geochem Geophys, Geosyst G3 6(6):Q06009. doi:10.1029/2004GC000896. ISSN: 1525-2027

Aytore B, Yalciner AC, Zaytsev A, Cankaya CZ, Suzen ML (2016) Assessment of tsunami resilience of Haydarpaşa Port in the Sea of Marmara by high-resolution numerical modeling. Earth Planets Space 201668:139. doi:10.1186/s40623-016-0508-z

Baștürk NB, Özel NM, Caciagli M (2016) Seismic parameters re-determined from historical seismograms of 1935-Erdek-Marmara Island and 1963-Çınarcık Earthquakes. Earth Planets Space. 68:158. doi:10.1186/ s40623-016-0528-8

Cankaya ZC, Suzen ML, Yalciner AC, Kolat C, Zaytsev A, Aytore B (2016) A new GIS-based tsunami risk evaluation: METU tsunami human vulnerability assessment (MeTHuVA) tsunami risk analysis Geographic information systems (GIS) Multi-criteria decision analysis (MCDA) Analytical hierarchical process (AHP) Tsunami Istanbul Yenikapı

Erdik M (2013) Earthquake risk in Turkey. Science 341:72

Erdik M, Demircioglu M, Sesetyan K, Durukal E, Siyahi B (2004) Earthquake hazard in Marmara region, Turkey. In: 13th world conference on earthquake engineering, Vancouver, BC, Canada August 1-6, 2004 paper no: 270

Hébert H, Schindelé F, Altinok Y, Alpar B, Gazioglu C (2005) Tsunami hazard in the Marmara Sea (Turkey): a numerical approach to discuss active faulting and impact on the Istanbul coastal areas. Mar Geol 215(1-2):23-43. doi:10.1016/j.margeo.2004.11.006
} 
Karagoz Ö, Chimoto K, Citak S, Ozel Ö, Yamanaka H, Hatayama K (2015) Estimation of shallow S-wave velocity structure and site response characteristics by microtremor array measurements in Tekirdag region, NW Turkey. Earth Planets Space 201567:176. doi:10.1186/s40623-015-0320-1

Meade BJ, Bradford HH, McClusky SC, Reilinger RE, Ergintav S, Lenk O, Barka A, Ozener H (2002) Estimates of seismic potential in the Marmara Sea region from block models of secular deformation constrained by global positioning system measurements. Bull Seismol Soc Am 92(1):208-215. doi:10.1785/0120000837

Mert A, Fahjan YM, Hutchings LJ, Pınar A (2016) Physically based probabilistic seismic hazard analysis using broadband ground motion simulation: a case study for the Prince Islands Fault, Marmara Sea. Earth Planets Space 201668:146. doi:10.1186/s40623-016-0520-3

Nakano M, Citak S, Kalafat D (2016) Focal mechanism determinations of earthquakes along the North Anatolian fault, beneath the Sea of Marmara and the Aegean Sea. Earth Planets Space 201567:159. doi:10.1186/ s40623-015-0330-z

Necmioğlu Ö (2016) Design and challenges for a tsunami early warning system in the Marmara Sea. Earth Planets Space 201668:13. doi:10.1186/ s40623-016-0388-2

Parsons T (2004) Recalculated probability of M $>7$ earthquakes beneath the Sea of Marmara, Turkey. J Geophys Res. doi:10.1029/2003JB002667

Pınar N (1943) Marmara Denizi Havzasının Sismik Jeoloji ve Meteorolojisi/ Géologie et Météorologie Sismique du Bassin de Mer Marmara. PhD thesis. Inst. Géol., Inst. Phys. Gén. Univ. İstanbul, Kenan Matbaası. 63 pp +1 foldout map

Pınar A, Coşkun Z, Mert A, Kalafat D (2016) Frictional strength of North Anatolian fault in eastern Marmara region. Earth Planets Space 68:62. doi:10.1186/s40623-016-0435-z

Polat G, Özel NM, Koulakov I (2016) Investigating P- and S-wave velocity structure beneath the Marmara region (Turkey) and the surrounding area from local earthquake tomography. Earth Planets Space 201668:132. doi:10.1186/s40623-016-0503-4
Pondard N, Armijo R, King GCP, Meyer B, Flerit F (2007) Fault interactions in the Sea of Marmara pull-apart (North Anatolian Fault): earthquake clustering and propagating earthquake sequences. Geophys J Int 171(3):1185-1197. doi:10.1111/j.1365-246X.2007.03580.x

Sahin A, Sisman R, Askan A, Hori M (2016) Development of integrated earthquake simulation system for Istanbul. Earth Planets Space 201668:115. doi:10.1186/s40623-016-0497-y

Şengör AMC, Grall C, Imren C, LePichon X, Görür N, Henry P, Karabulut H, Siyako M (2014) The geometry of the North Anatolian transform fault in the Sea of Marmara and its temporal evolution: implications for the development of intracontinental transform faults. Can J Earth Sci 51(3):222-242. doi:10.1139/cjes-2013-0160

Stein RS, Barka AA, Dieterich JH (1997) Progressive failure on the North Anatolian fault since 1939 by earthquake stress triggering. Geophys J Int 128:594-604

Straub, C., 1996. Recent crustal deformation and strain accumulation in the Marmara Sea region, NW Anatolia inferred from GPS measurements. PhD Thesis, ETH

Toksöz M, Shakal A, Michael A (1979) Space-time migration of earthquakes along the North Anatolian fault zone and seismic gaps. Pure appl Geophys 117:1258-1270

Yamamoto Y, Takahashi N, Citak S, Kalafat D, Pinar A, Gurbuz C, Kaneda Yoshiyuki (2015) Offshore seismicity in the western Marmara Sea, Turkey, revealed by ocean bottom observation. Earth Planets Space 201567:147. doi:10.1186/s40623-015-0325-9

Zülfikar AC, Fercan NÖZ, Tunç S, Erdik M (2017) Real-time earthquake shake, damage, and loss mapping for Istanbul metropolitan area. Earth Planets Space 201769:9. doi:10.1186/s40623-016-0579-x

\section{Submit your manuscript to a SpringerOpen ${ }^{\circ}$ journal and benefit from:}

- Convenient online submission

- Rigorous peer review

- Immediate publication on acceptance

- Open access: articles freely available online

- High visibility within the field

- Retaining the copyright to your article

Submit your next manuscript at $\boldsymbol{\nabla}$ springeropen.com 